\title{
Siberian weasel Mustela sibirica Pallas, 1773 predatism on bats during winter period
}

\author{
Alexander Zhigalin' \\ I National Research Tomsk State University, Tomsk, Russia \\ Corresponding author: Alexander Zhigalin (alex-zhigalin@mail.ru)
}

Academiceditor:O.T.Moldovan|Received24September2019|Accepted25November2019|Published6December 2019

http://zoobank.org/97E107F1-D8D9-4D4C-B24F-5FBD24EE6D5C

Citation: Zhigalin A (2019) Siberian weasel Mustela sibirica Pallas, 1773 predatism on bats during winter period.

Subterranean Biology 32: 111-117. https://doi.org/10.3897/subtbiol.32.46617

\begin{abstract}
This work presents the results of a three-year natural environment experiment in a cave in Barsukovskaya, Siberia), aimed at assessing the possible impact of mammals preying on a wintering group of bats. The average consumed biomass amount per year was about $2108 \mathrm{~g}$ and the estimated number of prey animals was 214 , which is about $20 \%$ of the maximum number of animals observed. The biomass consumed poorly correlates with the number of animals in the cave. The proportion of the various species remaining in the excrement of predators is strongly determined by the number of these species in the accessible part of the cave. The amount of excrement indicates the regular predatism on bats and, therefore, the presence of specific behavioural adaptation in Mustela sibirica.
\end{abstract}

\section{Keywords}

cave, Siberia, Vespertilionidae, Altai-Sayan

\section{Introduction}

The majority of works devoted to predatism on bats note the random nature of this phenomenon (Ryberg 1947; Dwyer 1964; Gillette and Kimbrough 1970; Taylor 1964; Fenton and Fleming 1976; Sparks et al. 2000; Molinari et al. 2005). Only a few studies indicate the possibility of species specialisation for hunting chiropterans (Bauer 1956; Black et al. 1979; Estók et al. 2009) which leads to insignificant losses in the prey population. However, the cited works mention targeted hunting for birds.

Copyright Alexander Zhigalin. This is an open access article distributed under the terms of the Creative Commons Attribution License (CC BY 4.0), which permits unrestricted use, distribution, and reproduction in any medium, provided the original author and source are credited. 
Data on winter preying by mammals on bats are scarce (Tiunov and Yudin 1986; Dulitsky 2001; Khritankov and Shishikin 2001; Sparks et al. 2003) and do not provide a quantitative assessment of the predator impact, whereas groups of bats, wintering in underground and other shelters, are most vulnerable to mammals.

This work presents the results of a three-year natural environment experiment, aimed at assessing the possible impact of mammals preying on a wintering group of bats.

A case of bats predation by Mustela sibirica Pallas, 1773 is addressed. The area of siberian weasel is mainly in Asia. It inhabits mainly forest and forest-steppe spaces, often settling near rivers. The basis of the diet in natural landscapes are small mammals and birds.

\section{Methods}

To estimate the impact of predators on the wintering group of bats, observations were made in Barsukovskaya cave $\left(54^{\circ} 22.15^{\prime} \mathrm{N}, 83^{\circ} 57.39^{\prime} \mathrm{E}\right)$ located in Altai-Sayan mountain country of the Salair ridge western spurs in the forest-steppe zone at an altitude of $181 \mathrm{~m}$ above sea level. The entrance to the cave is located on the southern slope which is covered with grassy, shrubby and woody vegetation (Figure 1). The river Ukrop is $50 \mathrm{~m}$ from the entrance while poplars, birch and bird cherry grow in the bottom area. Barsukovskaya cave is of karst origin and is a corridor-labyrinth type. The depth of the cave is $19 \mathrm{~m}$, the length is $100 \mathrm{~m}$. The average passage height is about 1.5 meters (minimum $30 \mathrm{~cm}$; maximum $-5 \mathrm{~m}$ ), average stroke width of about $2 \mathrm{~m}$ (minimum $-60 \mathrm{~cm}$; maximum $-12 \mathrm{~m}$ ). On the walls and ceiling there are a large number of ledges and cracks.

The cave is located in the continental climate zone. The average annual air temperature is $0.2^{\circ} \mathrm{C}$. The duration of the cold period is 178 , warm -188 , frost-free -120 days. The annual rainfall is $\approx 425 \mathrm{~mm}$. The air temperature in the cave does not fall below $+3{ }^{\circ} \mathrm{C}$.

In September 2015, excrement from Mustela sibirica Pallas, 1773 was discovered in the cave. The species identification was carried out via excrement size and shape (Formozov 2018). The bottom of the cave was cleared of all excrement at that time. The cave examinations were carried out from December 2015 to December 2017, when excrement was collected and the number and species of the wintering animals were determined.

The collected excrement was kept in a dry-heat oven for 3 hours at a temperature of $120^{\circ} \mathrm{C}$ then weighed to the limits of a centigram. To identify the content of excrement, it was saturated with water and studied in a Petri dish with a microscope. The identification of the species of prey animals was determined through the occurrence of their species-specific skulls parts (e.g. jaws or their parts, molars, tympanic bones or skull occipital parts).

To estimate the biomass consumed, a correction index showing the ratio between the consumed biomass of prey and undigested residues was used (Lockie 1961; Brzeziński and Marzec 2003). Due to the lack of experimental data on the index value for bats, values for small mammals (rodents, insectivores) of 22 were used (Lockie 1961). Having determined the occurrence of each object in the diet and, thereby, the share of its biomass from the total and dividing by the average mass of the prey in the winter, the number of consumed chiropteran individuals was obtained. 


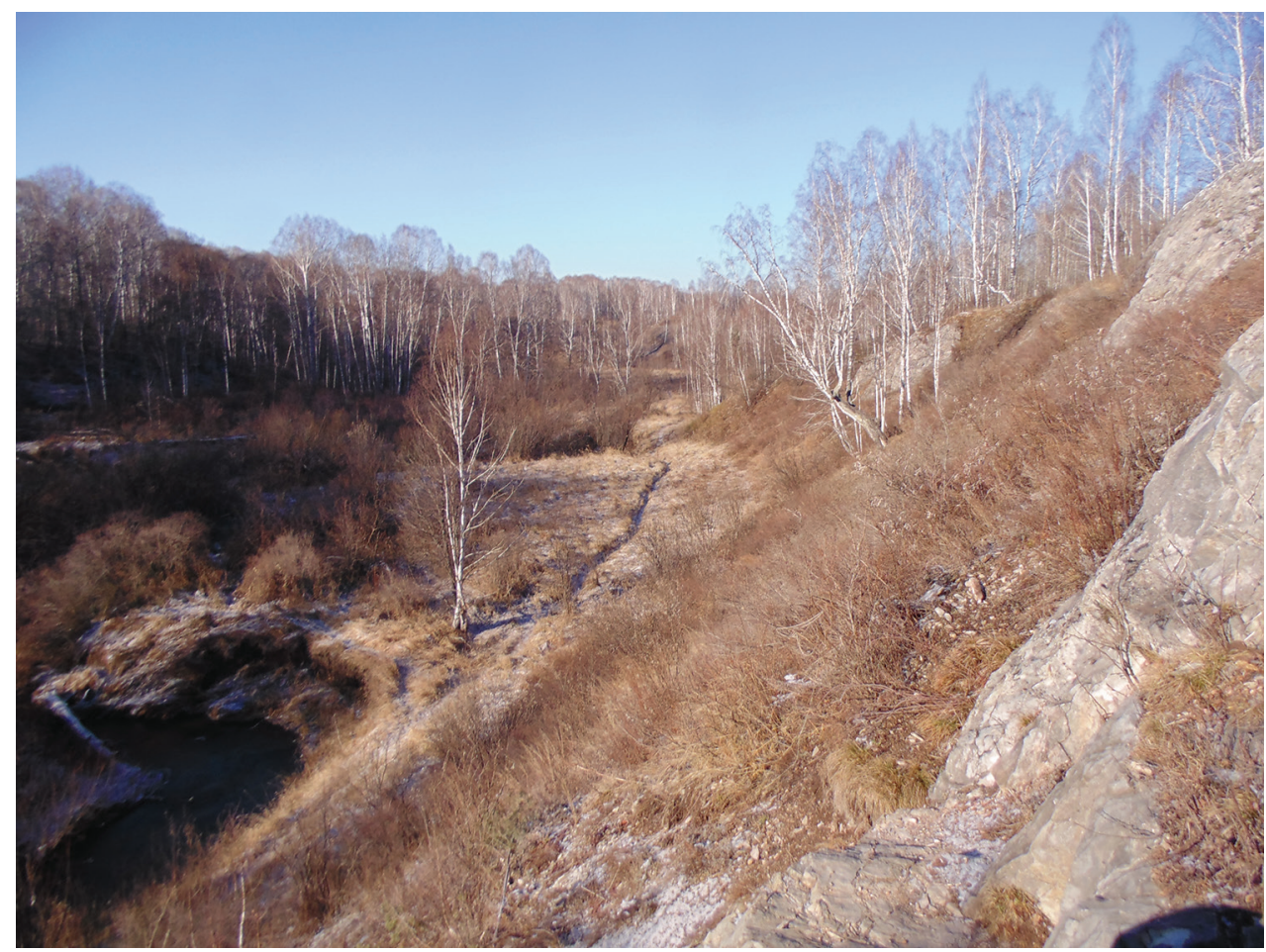

Figure I. Landscape at the entrance to Barsukovskaya cave (author photo).

Table I. Weather conditions during the research period.

\begin{tabular}{cccccc}
\hline Period & $\begin{array}{c}\text { Average air } \\
\text { temperature }\left({ }^{\circ} \mathbf{C}\right)\end{array}$ & $\begin{array}{c}\text { Rainfall } \\
(\mathbf{m m})\end{array}$ & $\begin{array}{c}\text { Number of days } \\
\text { with precipitation }\end{array}$ & $\begin{array}{c}\text { Average snow } \\
\text { depth }(\mathbf{m m})\end{array}$ & $\begin{array}{c}\text { Maximum snow } \\
\text { depth }(\mathbf{m m})\end{array}$ \\
\hline $07.09 .2015-13.12 .2015$ & -0.7 & 181 & 63 & 138 & 330 \\
$13.12 .2015-20.12 .2016$ & -5.5 & 294 & 137 & 348 & 630 \\
$20.12 .2016-15.04 .2017$ & -10.6 & 92 & 65 & 640 & 840 \\
$15.04 .2017-01.12 .2017$ & 5.5 & 271 & 75 & 98 & 180 \\
\hline
\end{tabular}

In order to determine the average mass of species, individuals that were in an active state during the cave survey were weighed. Before weighing the animals were placed in a rag bag, with previously established mass. The measurements were carried out with an electronic weight-scales Pesola MS500. After weighing the animals were placed back on the walls of the cave.

The air temperature at the surface, precipitation and the snow-cover height were analysed for the whole observation period (Table 1), with the exception of the summer months when bats were only found sporadically in the cave (Zhigalin et al. 2019). Weather conditions were obtained from the nearest weather station archive, located in the village of Maslyanino $\left(54^{\circ} 21.15^{\prime} \mathrm{N}, 84^{\circ} 12.03^{\prime} \mathrm{E}\right)$.

The value of variables correlations was estimated with the Pearson coefficient. 


\section{Results}

In total, the cave was examined 5 times during the observation period. The examinations detected 2313 individuals of 6 species: Myotis petax Hollister, 1912, Myotis sibiricus Kastschenko, 1905, Myotis dasycneme (Boie, 1825), Eptesicus nilssonii (Keyserling, Blasius, 1839), Plecotus ognevi Kishida, 1927 and Murina hilgendorfi Peters, 1880 (Table 2).

M. petax and Mu. hilgendorfi (Figure 2) dominate in the cave, other species being found sporadically and not annually. In autumn and winter periods, most animals stay in the inaccessible parts of the cave; up to 300 individuals were found in the accessible area during different examinations. An exception was the beginning of winter 2017, when 615 animals were observed in the cave. The maximum number of bats in this shelter was found in the spring, when there were up to 1000-1300 individuals.

When examining the cave, most of the animals were located in the cavities and cracks of the ceiling. The number of animals on the walls of the cave and in their cracks in different periods ranged from 15 to $23 \%$. The minimum height from the ceiling where animals were located was $30 \mathrm{~cm}$, the maximum $-5 \mathrm{~m}$. Representatives of the Myotis and Murina genera, as a rule, are located in close proximity to each other, forming clusters of up to several dozen individuals. All individuals of E. nilssonii and P. ognevi held alone and located in the entrance part of the cave.

The average weight of the bat was calculated by weighing 348 Myotis petax, 8 Myotis sibiricus and 124 Murina hilgendorfi individuals. The study showed that the average mass of M. petax is about $9.0 \mathrm{~g}$, M. sibiricus $-7.7 \mathrm{~g}$ and $M u$. hilgendorf $-11.01 \mathrm{~g}$. The analysis of the weasel excrement showed that the remains belonged to three species of bats: $M$. petax, $M$. sibiricus and Mu. hilgendorfi (Table 3).

In the cave, the remains of an M. petax were discovered (Figure 3).
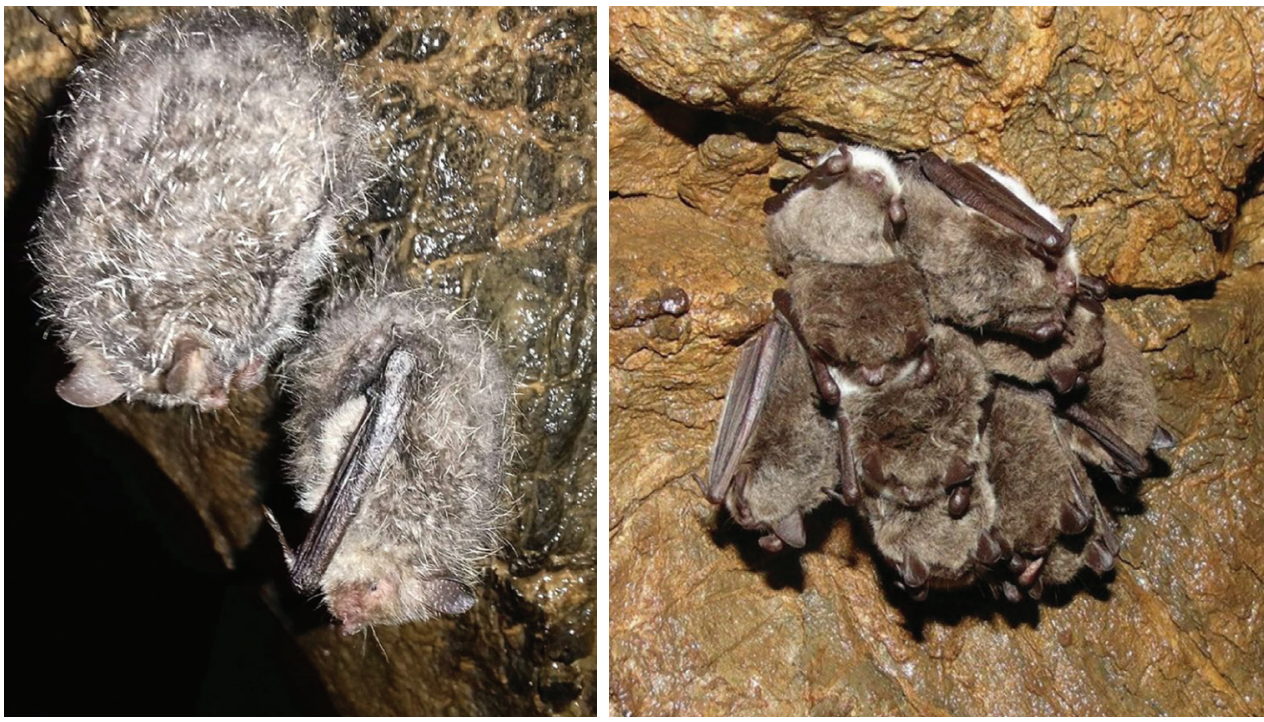

Figure 2. Mu. hilgendorf (left) and M. petax (right) in Barsukovskaya cave (author photo). 
Table 2. The number of bats in the cave on the days of the survey.

\begin{tabular}{lccccc}
\hline \multicolumn{1}{c}{ Species } & $\mathbf{0 7 . 0 9 . 2 0 1 5}$ & $\mathbf{1 3 . 1 2 . 2 0 1 5}$ & $\mathbf{2 0 . 1 2 . 1 6}$ & $\mathbf{1 5 . 0 4 . 2 0 1 7}$ & $\mathbf{0 1 . 1 2 . 2 0 1 7}$ \\
\hline M. petax & 57 & 198 & 136 & 543 & 348 \\
M. sibiricus & 2 & - & 6 & - & - \\
M. dasycneme & - & - & - & 27 & - \\
M. hilgendorf & - & 56 & 170 & 498 & 267 \\
E. nilssonii & - & - & 2 & - & - \\
P. ognevii & - & - & 3 & - & - \\
Total & 59 & 254 & 317 & 1068 & 615 \\
\hline
\end{tabular}

Table 3. The occurrence of bats remains in Mustela sibirica coprological material, estimated biomass and the number of prey animals.

\begin{tabular}{ccccc}
\hline $\begin{array}{c}\text { Period of accumulation } \\
\text { of excrement }\end{array}$ & Species & $\begin{array}{c}\text { Frequency of } \\
\text { occurrence (\%) }\end{array}$ & $\begin{array}{c}\text { Calculated biomass } \\
(\mathbf{g})\end{array}$ & $\begin{array}{c}\text { Calculated number } \\
\text { of eaten individuals }\end{array}$ \\
\hline $07.09 .2015-13.12 .2015$ & M. petax & 63.8 & 589.5 & 65.5 \\
& Mu. hilgendorf & 36.2 & 334.8 & 30.4 \\
& Total & 100 & 924.3 & 95.9 \\
$13.12 .2015-20.12 .2016$ & M. petax & 47.7 & 566.7 & 62.9 \\
& Mu. hilgendorf & 52.3 & 621.3 & 56.4 \\
& Total & 100 & 1188 & 119.3 \\
$20.12 .2016-15.04 .2017$ & M. petax & 60.2 & 1123.9 & 124.9 \\
& Mu. hilgendorf & 39.1 & 729.9 & 66.4 \\
& M. sibiricus & 0.7 & 13.1 & 0.93 \\
$15.04 .2017-01.12 .2017$ & Total & 100 & 1876 & 192.23 \\
& M. petax & 52.1 & 389.2 & 43.2 \\
& Mu. hilgendorf & 47.9 & 357.8 & 32.5 \\
& Total & 100 & 747 & 75.7 \\
\hline
\end{tabular}

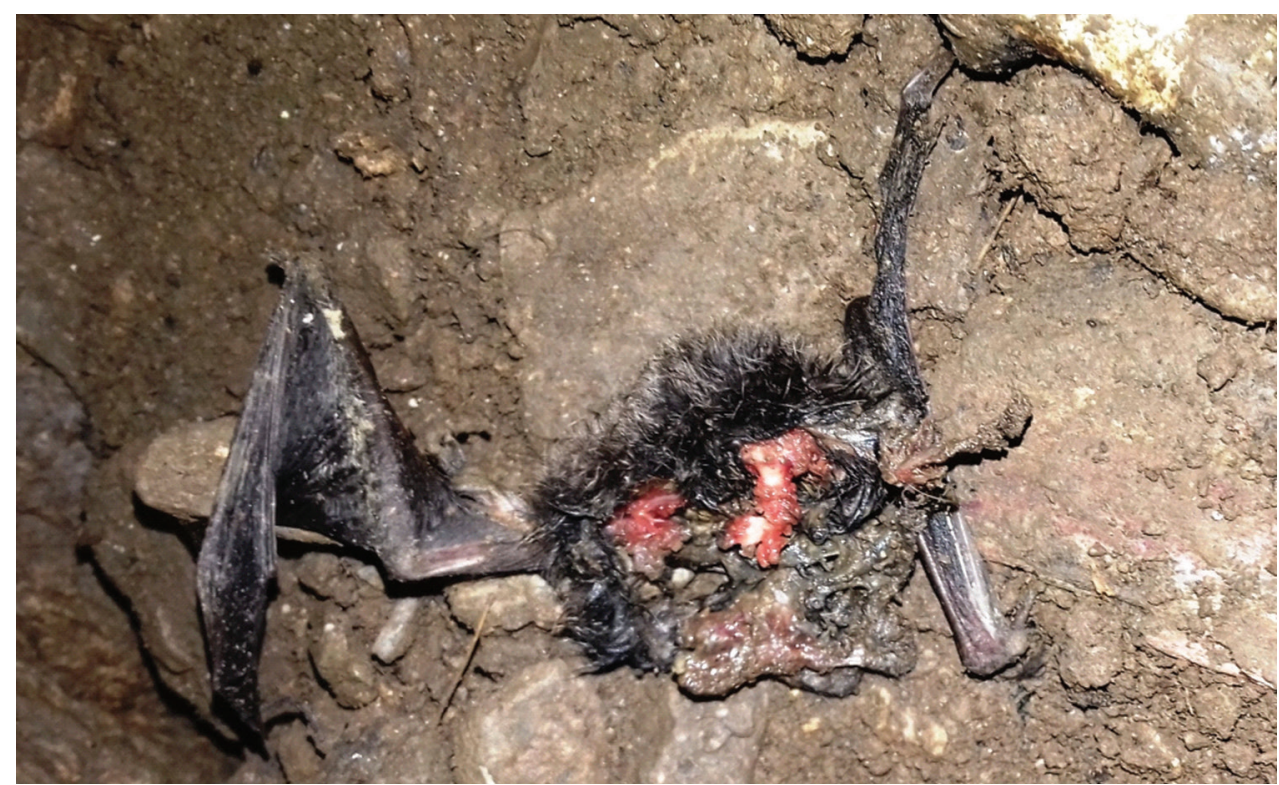

Figure 3. Remains of a bat discovered in a cave 15.04.2017 (author photo). 


\section{Discussion}

During the cave survey, the Mustela sibirica excrement was found in all parts, including the deepest cavities. The excrement study showed that it consists fully of bats remains (wool, bones), which makes this case unique. In previous studies, the maximum proportion of bat remains in predator droppings was no more than $75 \%$ in sable Martes zibellina L., 1758, which hunts in the cave of the Stolby reserve (Khritankov and Shishikin 2001). The absence of the remains of other animals and plants in the studied material may indicate that the predator entering the cave was very hungry. It was also found that the biomass consumed poorly correlates with the number of animals in the cave $(\mathrm{r}=0.73 ; \mathrm{p}>0.05)$.

The data shows that most of the prey are $M$. petax, which account for up to $63.8 \%$ of all remains. The proportion of the remains of $M u$. hilgendorf is up to $52.3 \%$. The proportion of the remains of various species in the excrement is strongly determined by the number of these species in the accessible part of the cave $(r=0.7 ; p<0.05)$. The proportional ratio of the species number and their remains in the excrement indicate the absence of species preferences in the predator.

The average consumed biomass amount per year is about $2108 \mathrm{~g}$ and the estimated number of prey animals is 214 , which is about $20 \%$ of the maximum number of animals observed.

Correlation analysis revealed that the amount of consumed biomass is connected with the average snow cover height $(\mathrm{r}=0.99 ; \mathrm{p}<0.01)$ and its maximum values $(\mathrm{r}=$ $0.95 ; \mathrm{p}<0.05)$. The reason for this, in our opinion, is that with an increase in snow cover, hunting for small mammals becomes more energy-consuming and less effective.

The siberian weasel hunting strategy for bats remains unclear. Apparently, Mustela sibirica hunts animals that are located closest to the floor of the cave, climbing via the cracks to reach the bats. This strategy has already been recorded in another location in Siberia (Khritankov and Shishikin 2001). Active hunting for awakened and flying bats is also possible, which is most typical for siberian weasel.

\section{Conclusion}

The amount of excrement indicates the regular predatism on bats and, therefore, the presence of specific behavioural adaptation in Mustela sibirica. The calculated values of the prey number indicate significant losses in the bat group due to the hunting of Mustela sibirica. Hunting for chiropterans, perhaps, is a more efficient way to forage with lower energy costs in the snowy period.

\section{Acknowledgements}

The study was carried out within the framework of the programme for improving the competitiveness of the National Research Tomsk State University and was supported by the fund of D.I. Mendeleev. 


\section{References}

Bauer K (1956) Schleiereule (Tyro alba Scop.) als Fledermausjager. Journal of Ornithology 97: 335-340. https://doi.org/10.1007/BF01973733

Black HL, Howard G, Stjernstedt R (1979) Observations on the feeding behavior of the Bat Hawk (Macheiromphus alcinus). Biotropica 11: 18-21. https://doi.org/10.2307/2388165

Brzeziński M, Marzec M (2003) The origin, dispersal and distribution of the American mink Mustela vison in Poland. Acta theriologica 48: 505-514. https://doi.org/10.1007/ BF03192496

Dulitsky AI (2001) Biodiversity of Crimea. Mammals: history, condition, conservation, prospects. Simferopol, 208 pp. [In Russian]

Dwyer PD (1964) Fox predation on cave-bats. Australian Journal of Science 26: 397-398.

Estók P, Zsebők S, Siemers BM (2009) Great tits search for, capture, kill and eat hibernating bats. Biology letters 6: 59-62. https://doi.org/10.1098/rsbl.2009.0611

Fenton MB, Fleming TH (1976) Ecological interactions between bats and nocturnal birds. Biotropica 6: 104-110. https://doi.org/10.2307/2989629

Formozov AN (2018) Tracker Companion. Moscow, AST, 448 pp. [In Russian]

Gillette DD, Kimbrough JD (1970) Chiropteran Mortality. In: Slaughter BH, Walton DW (Eds) About Bats. Dallas Southern Methodist University Press, Dallas, 262-281.

Khritankov AM, Shishikin AS (2001) Natural enemies of bats in Central Siberia. Proceedings of the Stolby State Reserve 16: 95-102. [In Russian]

Lockie JD (1961) The food of the pine Marten martes in west Ross-Shire, Scotland. Journal of Zoology 136: 187-195. https://doi.org/10.1111/j.1469-7998.1961.tb06171.x

Molinari J, Gutiérrez EE, Ascenção AA, Nassar JM, Arends A, Marquez RJ (2005) Predation by giant centipedes, Scolopendra gigantea, on three species of bats in a Venezuelan cave. Caribbean Journal of Science 41: 340-346.

Ryberg O (1947) Studies on bats and bat parasites. Lund, Sweden: Berlingska Boktrykeriet. Sparks DW, Roberts KJ, Jones C (2000) Vertebrate predators on bats in North America north of Mexico. In: Choate JR (Ed.) Reflections of a naturalist: papers honoring Professor Eugene D. Fleharty. Sternberg Museum of Natural History, Fort Hays State University, Hays, Kansas, 229-241.

Sparks DW, Simmons MT, Gummer CL, Duchamp JE (2003) Disturbance of roosting bats by woodpeckers and raccoons. Northeastern Naturalist 10: 105-109. https://doi. org/10.2307/3858677

Taylor WP (1964) Noteworthy predation on the guano bat. Journal of Mammalogy 45: 300 301. https://doi.org/10.2307/1376997

Tiunov MP, Yudin VG (1986) Sable predation at bats wintering (Chiroptera). Ecology 5: 8485. [In Russian]

Zhigalin AV, Gadzhiev AA, Daudova MG, Salimkhanov NG, Shestopalov AM (2019) Ecology of chiroptera bats in Altai-Sayan region of Southern Siberia. South of Russia: ecology, development 14: 9-25. https://doi.org/10.18470/1992-1098-2019-1-9-25 [In Russian] 